\title{
Argadin, a New Chitinase Inhibitor, Produced by Clonostachys sp. FO-7314
}

\author{
Noriko Arai,${ }^{a}$ Kazuro Shiomi,${ }^{a}$ Yuuichi YAmaguchi, ${ }^{a}$ Rokuro Masuma,,${ }^{a}$ Yuzuru IwaI, ${ }^{a}$ \\ Andreas Turberg, ${ }^{b}$ Heinz KölBL ${ }^{b}$ AND SATOSHI ŌMUrA ${ }^{*, a}$ \\ Research Center for Biological Function. The Kitasato Institute, ${ }^{a}$ 5-9-1 Shirokane, Minato-ku, Tokyo 108-8642, Japan \\ and Bayer AG, Biological Technology Center, Business Group Animal Health, ${ }^{b}$ D-51368 Leverkusen, Germany. \\ Received June 2, 2000; accepted July 11, 2000
}

\begin{abstract}
A new chitinase inhibitor, designated as argadin (1), was isolated from the cultured broth of a fungal strain FO-7314. The strain was identified as Clonostachys sp. from the morphological characteristics. Argadin was purified from the cultured mycelium by a combination of cation exchange, adsorption and gel filtration chromatographic methods. The structure of argadin was elucidated as $\operatorname{cyclo}\left(N^{\omega}{ }^{-}\right.$-acetyl-L-arginyl-D-prolyl-homoseryl-histidyl-L-2-aminoadipyl) in which homoseryl $\gamma$-methylene bonded to histidyl $\alpha$-amino residue. $\mathrm{The}^{\mathrm{IC}_{50}}$ value of argadin against Lucilia cuprina (blowfly) chitinase was $150 \mathrm{~nm}$ at $37^{\circ} \mathrm{C}$ and $3.4 \mathrm{~nm}$ at $20^{\circ} \mathrm{C}$. Argadin arrested the moult of cockroach larvae upon injection into the ventral abdominal part.
\end{abstract}

Key words chitinase inhibitor; cyclic peptide; Clonostachys; argadin; microbial metabolite

Chitin occurs in fungi, some algae and many invertebrates including insects, but is not found in vertebrates. Thus chitin synthesis and degradation processes might be expected to be specific targets for fungicides and insecticides. ${ }^{1,2)}$ Though chitin synthesis inhibitors, such as fungicidal polyoxins and insecticidal benzoylphenylureas, are commercially available, chitin degradation inhibitors have not yet been used. Chitinase (EC 3.2.1.14) is a chitin degradation enzyme and hydrolyzes chitin into oligomer of $N$-acetylglucosamine. Only few inhibitors have been reported, e.g. allosamidin, ${ }^{3)}$ styloguanidine ${ }^{4)}$ and cyclo(L-arginyl-D-prolyl). ${ }^{5)}$ An inhibitor of chitinase would be expected to inhibit apolysis during the insect moulting and prevent maturation to the adult reproductive stage.

In the course of screening for new insecticides of microbial origin, we previously reported a new cyclic pentapeptide chitinase inhibitor, argifin (2), which was the first inhibitor produced by fungi and showed inhibition in a submicromolar range. ${ }^{6-8)}$ Our continuing screening efforts to find chitinase inhibitors were rewarded by finding of a new compound, argadin (1, Fig. 1), from the cultured broth of Clonostachys sp. FO-7314.

In this paper, we report on the isolation, structure elucidation and biological properties of 1 as well as the taxonomy of the producing organism.

\section{Results and Discussion}

Taxonomy of Strain FO-7314 The fungal strain was isolated from a soil sample collected on Oshima Island, Tokyo, Japan. Morphological properties were examined after incubation at $25^{\circ} \mathrm{C}$ for $14 \mathrm{~d}$ on potato dextrose agar (Difco), cornmeal agar (Difco), Czapek agar (3.0\% sucrose, $0.2 \%$ $\mathrm{NaNO}_{3}, 0.1 \% \mathrm{~K}_{2} \mathrm{HPO}_{4}, 0.05 \% \mathrm{KCl}, 0.05 \% \mathrm{MgSO}_{4} \cdot 7 \mathrm{H}_{2} \mathrm{O}$, $0.001 \% \mathrm{FeSO}_{4} \cdot 7 \mathrm{H}_{2} \mathrm{O}$ and $2.0 \%$ agar, $\mathrm{pH} 6.0$ ), Miura's medium $\left(0.1 \%\right.$ glycerol, $0.08 \% \mathrm{KH}_{2} \mathrm{PO}_{4}, 0.02 \% \mathrm{~K}_{2} \mathrm{HPO}_{4}$, $0.02 \% \mathrm{MgSO}_{4} \cdot 7 \mathrm{H}_{2} \mathrm{O}, 0.02 \% \mathrm{KCl}, 0.2 \% \mathrm{NaNO}_{3}, 0.02 \%$ yeast extract and $1.5 \%$ agar, $\mathrm{pH} 6.0$ ), and malt extract agar (2.0\% malt extract, $0.1 \%$ peptone, $2.0 \%$ glucose and $2.0 \%$ agar, $\mathrm{pH}$ 6.0). The strain grew moderately to form white colonies with diameters of $40-50 \mathrm{~mm}$. Reverse of the colonies was white to pale yellow. The colonies were floccose to powdery on each medium. Microscopic observation showed that conidiophores $(45-100 \times 2.5-3.5 \mu \mathrm{m})$ were branched two or more times, and their upper portions bore penicillate branches. Phialides that grew on the penicillate branches were enteroblastic, phialidic, obclavate and 10$14 \times 1.5-3.0 \mu \mathrm{m}$ in size. Phialoconidia were ellipsoidal to cylindrical, $5.5-7.5 \times 1.5-2.0 \mu \mathrm{m}$ in size, viscous and producing long chains more than $100 \mu \mathrm{m}$ length in a spicate form (Fig. 2).

From the above characteristics, strain FO-7314 was believed to belong to the genus Clonostachys and named
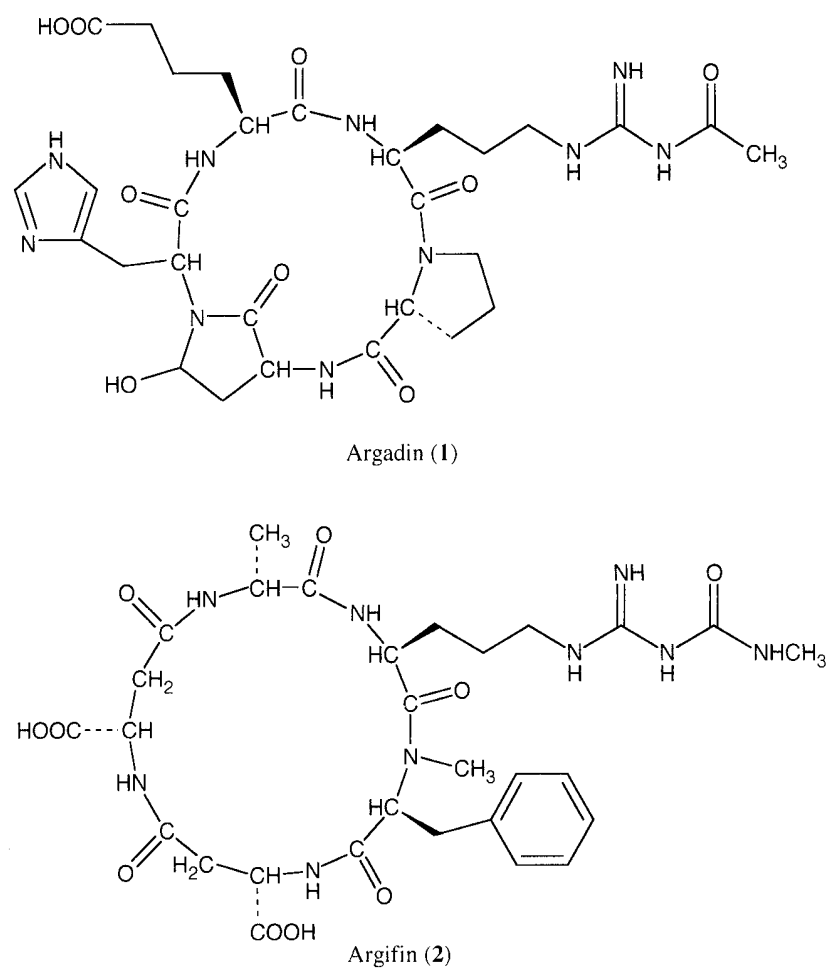

Fig. 1. Structure of Argadin (1) and Argifin (2) 


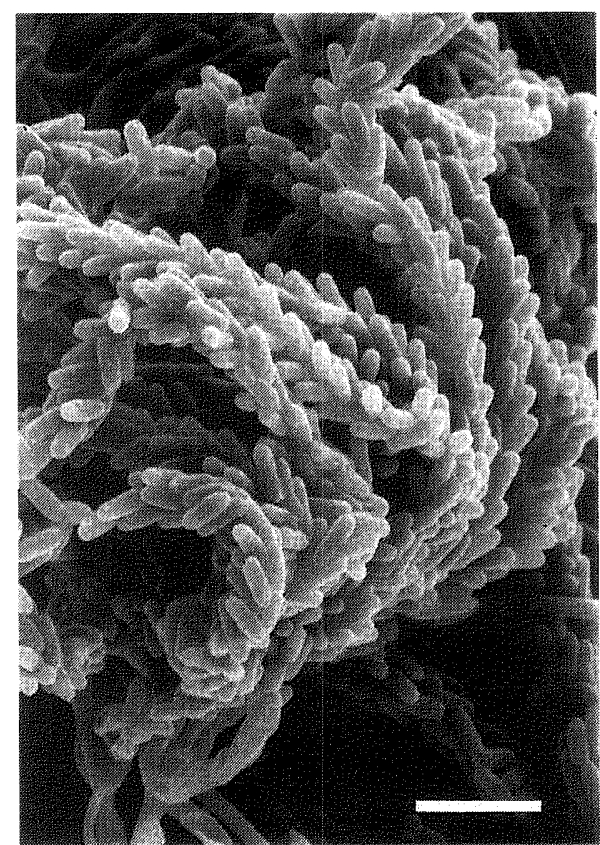

Fig. 2. Electromicrograph of Phialoconidia of Strain FO-7314 Bar represents $10 \mu \mathrm{m}$

Clonostachys sp. FO-7314. The culture was deposited at the Fermentation Research Institute, Agency of Industrial Science and Technology Japan, as FERM P-17200.

Fermentation and Isolation A stock culture of strain FO-7314 grown on potato dextrose agar was inoculated into a $500-\mathrm{ml}$ Erlenmeyer flask containing $100 \mathrm{ml}$ of a seed medium and incubated on a rotary shaker $(210 \mathrm{rpm})$ at $27^{\circ} \mathrm{C}$ for $4 \mathrm{~d}$. One milliliter of the seed culture was transferred into each of eighty $500-\mathrm{ml}$ Erlenmeyer flasks containing $100 \mathrm{ml}$ of a production medium. The fermentation was carried out on a rotary shaker at $27^{\circ} \mathrm{C}$ for $6 \mathrm{~d}$. Compound 1 was produced mainly in mycelia.

Compound 1 was extracted with methanol from the mycelia from the cultured broth of FO-7314 (81). It was purified successively by a cation exchange column Diaion SK1B $\left(\mathrm{NH}_{4}{ }^{+}\right.$form, Mitsubishi Chemical Corp.), an adsorption column Diaion HP20 (Mitsubishi Chemical Corp.), a cation exchange column SP-Sephadex C-25 $\left(\mathrm{NH}_{4}{ }^{+}\right.$form, Amersham Pharmacia Biotech), an octadecyl silica (ODS) column (Pegasil ODS-7515-12A, Senshu Scientific Co.), a Sephadex LH-20 column (Amersham Pharmacia Biotech), and a BioGel P-2 Gel column (fine, Bio-Rad). Twenty-five milligrams of a white powder of 1 was ultimately obtained. It showed a single spot on a silica gel TLC (Merck 1.05715, developed with $80 \% n$-propanol) detected by ninhydrin reagent.

Structure Elucidation The molecular formula of $\mathbf{1}$ was established as $\mathrm{C}_{29} \mathrm{H}_{42} \mathrm{~N}_{10} \mathrm{O}_{9}$ based on high resolution (HR)FAB-MS. Compound $\mathbf{1}$ was soluble in acidic water and acidic dimethyl sulfoxide (DMSO), slightly soluble in water and DMSO, and insoluble in methanol, acetone and chloroform. Compound $\mathbf{1}$ gave positive reactions by both Rydon-Smith and ninhydrin reagents. A strong band at $1650 \mathrm{~cm}^{-1}$ in the IR spectrum indicated the presence of amide linkages.

Chemical shifts in the ${ }^{1} \mathrm{H}-,{ }^{13} \mathrm{C}$ - and ${ }^{15} \mathrm{~N}-\mathrm{NMR}$ of $\mathbf{1}$ are shown in Table 1. The HMQC (heteronuclear multiple quantum coherence) experiment revealed the connectivity of each
Table 1. The ${ }^{1} \mathrm{H}-,{ }^{13} \mathrm{C}$ - and ${ }^{15} \mathrm{~N}-\mathrm{NMR}$ Data of $\mathbf{1}^{(t)}$

\begin{tabular}{|c|c|c|c|}
\hline Position & ${ }^{13} C^{b)}$ & ${ }^{1} \mathrm{H}^{h,(c)}$ & ${ }^{15} \mathrm{~N}^{d)}$ \\
\hline \multicolumn{4}{|l|}{ Acetyl } \\
\hline $\mathrm{C}=\mathrm{O}$ & $172.7 \mathrm{~s}$ & & \\
\hline $\mathrm{Me}$ & $24.1 \mathrm{q}$ & $2.10 \mathrm{~s}$ & \\
\hline \multicolumn{4}{|l|}{ Arginine } \\
\hline $\mathrm{NH}$ & & $8.58 \mathrm{~d}(6.8)$ & 125.0 \\
\hline $\mathrm{C}=\mathrm{O}$ & $170.1 \mathrm{~s}$ & & \\
\hline$\alpha$ & $51.6 \mathrm{~d}$ & $4.10 \mathrm{~m}$ & \\
\hline$\beta$ & $27.4 \mathrm{t}$ & $1.66 \mathrm{~m}, 1.73 \mathrm{~m}$ & \\
\hline$\gamma$ & $24.3 \mathrm{t}$ & $1.50 \mathrm{~m}$ & \\
\hline$\delta$ & $40.7 \mathrm{t}$ & $3.25 \mathrm{~m}$ & \\
\hline$\varepsilon$ & & $9.16+(4.8)$ & 97.4 \\
\hline$\zeta$ & $153.1 \mathrm{~s}$ & & \\
\hline$\eta_{1}$ & & $11.78 \mathrm{~s}$ & 133.3 \\
\hline$\eta_{2}$ & & 8.68 brs & 84.7 \\
\hline \multicolumn{4}{|l|}{ Proline } \\
\hline $\mathrm{N}$ & & & 137.4 \\
\hline $\mathrm{C}=\mathrm{O}$ & $171.1 \mathrm{~s}$ & & \\
\hline$\alpha$ & $59.8 \mathrm{~d}$ & $4.59 \mathrm{~m}$ & \\
\hline$\beta$ & $27.9 \mathrm{t}$ & $1.75 \mathrm{~m}, 2.11 \mathrm{~m}$ & \\
\hline$\gamma$ & $23.6 \mathrm{t}$ & $1.75 \mathrm{~m}, 3.28 \mathrm{~m}$ & \\
\hline$\delta$ & $46.0 \mathrm{t}$ & $\begin{array}{l}3.31 \mathrm{~m} \text {, } \\
3.41 \mathrm{ddd}(11.4,11.4,11.4)\end{array}$ & \\
\hline \multicolumn{4}{|c|}{ Homoserine } \\
\hline NH & & $7.16 \mathrm{~d}(9.1)$ & 123.1 \\
\hline $\mathrm{C}=\mathrm{O}$ & $172.9 \mathrm{~s}$ & & \\
\hline$\alpha$ & $49.0 \mathrm{~d}$ & 4.33 ddd $(4.3,9.1,11.6)$ & \\
\hline$\beta$ & $35.9 \mathrm{t}$ & $\begin{array}{l}1.66 \mathrm{~m} \\
2.63 \mathrm{ddd}(6.2,11.6,19.4)\end{array}$ & \\
\hline$\gamma$ & $78.7 \mathrm{~d}$ & $5.31 \mathrm{~d}(6.2)$ & \\
\hline \multicolumn{4}{|l|}{ Histidine } \\
\hline $\mathrm{N}$ & & & 150.2 \\
\hline $\mathrm{C}=\mathrm{O}$ & $169.9 \mathrm{~s}$ & & \\
\hline$\alpha$ & $57.2 \mathrm{~d}$ & $4.58 \mathrm{~m}$ & \\
\hline$\beta$ & $22.5 \mathrm{t}$ & $\begin{array}{l}3.26 \mathrm{dd}(9.6,19.9) \\
3.36 \mathrm{dd}(12.6,19.9)\end{array}$ & \\
\hline$\gamma$ & $129.4 \mathrm{~s}$ & & \\
\hline$\pi$ & & & 179.1 \\
\hline$\delta$ & $117.0 \mathrm{~d}$ & $7.43 \mathrm{~s}$ & \\
\hline$\varepsilon$ & $134.5 \mathrm{~d}$ & $8.97 \mathrm{~s}$ & \\
\hline$\tau$ & & $14.19 \mathrm{brs}$ & 172.1 \\
\hline \multicolumn{4}{|c|}{ 2-Aminoadipic acid } \\
\hline $\mathrm{NH}$ & & $8.27 \mathrm{~d}(7.9)$ & 122.1 \\
\hline $\mathrm{C}=\mathrm{O}$ & $171.4 \mathrm{~s}$ & & \\
\hline$\alpha$ & $53.2 \mathrm{~d}$ & $4.08 \mathrm{~m}$ & \\
\hline$\beta$ & $31.8 \mathrm{t}$ & $1.57 \mathrm{~m}, 1.66 \mathrm{~m}$ & \\
\hline$\gamma$ & $20.7 \mathrm{t}$ & $1.43 \mathrm{~m}$ & \\
\hline$\delta$ & $33.1 \mathrm{t}$ & $\begin{array}{l}2.17 \text { ddd }(9.1,16.9,21.3) \\
2.21 \text { ddd }(9.1,16.9,21.3)\end{array}$ & \\
\hline$\varepsilon$ & $174.3 \mathrm{~s}$ & & \\
\hline
\end{tabular}

a) The spectra were obtained with Varian Inova 600 and Unity 400 spectrometers. b) Solvent: DMSO- $d_{6}$ with $1.7 \%$ TFA. c) The coupling constants $(\mathrm{Hz})$ are in parentheses. d) Solvent: $\mathrm{H}_{2} \mathrm{O}-\mathrm{D}_{2} \mathrm{O}(4: 1)$ with $2 \%$ TFA.

proton and carbon. In the DEPT (distortionless enhancement by polarization transfer) spectra, 1 showed 1 methyl, 11 methylene, 8 methine and 9 quaternary carbon signals. The ${ }^{1} \mathrm{H}-\mathrm{NMR}$ spectrum showed 40 proton signals, whereas the remaining 2 hydrogens were not observed in either spectrum. The ${ }^{15} \mathrm{~N}$ signals obtained by $f_{1}$ projection of the ${ }^{1} \mathrm{H}-{ }^{15} \mathrm{~N}$ HMBC (heteronuclear multiple bond coherence) indicated 10 nitrogens.

Presence of partial structures a-f (Fig. 3) were elucidated by ${ }^{1} \mathrm{H}-{ }^{1} \mathrm{H}$ COSY (correlation spectroscopoy) and ${ }^{1} \mathrm{H}-{ }^{13} \mathrm{C}$ HMBC experiments in DMSO- $d_{6}$ containing $1.7 \%$ trifluoracetic acid (TFA). The partial structures a-f were deduced to be arginine (a), proline (b), homoserine (Hse, c), histidine 


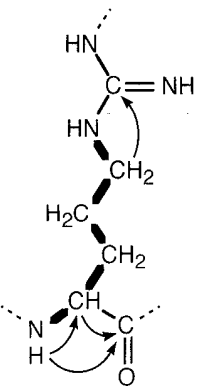

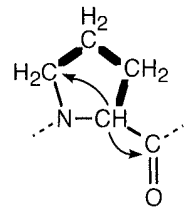

b

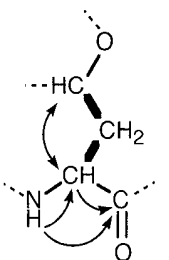

c

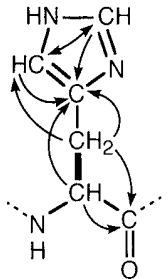

d

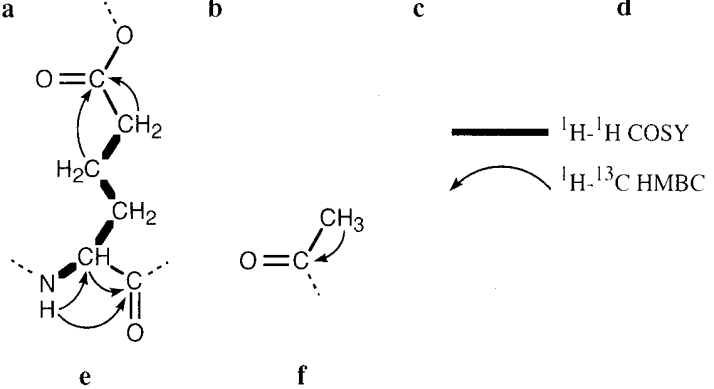

Fig. 3. Partial Structures of 1

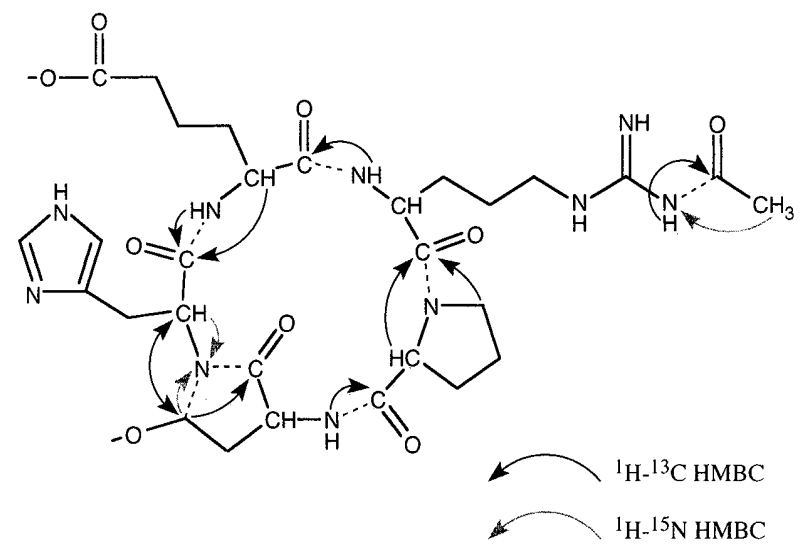

Fig. 4. Structure of $\mathbf{1}$ Elucidated by ${ }^{1} \mathrm{H}-{ }^{13} \mathrm{C}$ HMBC and ${ }^{1} \mathrm{H}-{ }^{15} \mathrm{~N}$ HMBC

(d), 2-aminoadipic (Aad, e) and acetyl (f) residues.

The connectivity of the partial structures $\mathbf{a}-\mathbf{f}$ was determined from long-range couplings of ${ }^{1} \mathrm{H}-{ }^{13} \mathrm{C}$ HMBC and ${ }^{1} \mathrm{H}-{ }^{15} \mathrm{~N}$ HMBC (Fig. 4). A long-range ${ }^{1} \mathrm{H}-{ }^{13} \mathrm{C}$ coupling was observed from Pro $\alpha-\mathrm{CH}\left(\delta_{\mathrm{H}} 4.59\right)$ to $\operatorname{Arg}$ carbonyl $\left(\delta_{\mathrm{C}}\right.$ 170.1), which suggested the linkage of Arg (a)-Pro (b). A long-range coupling between Hse $\mathrm{NH}\left(\delta_{\mathrm{H}} 7.16\right)$ and Pro carbonyl $\left(\delta_{\mathrm{C}} 171.1\right)$ suggested the linkage of Pro $(\mathbf{b})-\mathrm{Hse}(\mathbf{c})$. Long-range couplings were also observed from Aad $\mathrm{NH}\left(\delta_{\mathrm{H}}\right.$ 8.27) and Aad $\alpha-\mathrm{CH}\left(\delta_{\mathrm{H}} 4.08\right)$ to His carbonyl $\left(\delta_{\mathrm{C}} 169.9\right)$, which suggested the linkage of His (d)-Aad (e), and a longrange coupling between $\operatorname{Arg} \alpha$ - $\mathrm{NH}\left(\delta_{\mathrm{H}} 8.58\right)$ and Aad carbonyl $\left(\delta_{\mathrm{C}}\right.$ 171.4) suggested the linkage of $\operatorname{Aad}(\mathbf{e})-\operatorname{Arg}(\mathbf{a})$.

The homoseryl $\gamma$-carbon was shown to be a methine. The amide linkage between Hse (c)-His (d) and a bond between Hse $\gamma$-CH and His $\alpha$-N were suggested by long-range couplings from Hse $\gamma-\mathrm{CH}\left(\delta_{\mathrm{H}} 5.31\right)$ to Hse carbonyl $\left(\delta_{\mathrm{C}} 172.9\right)$ and $\mathrm{His} \alpha-\mathrm{CH}\left(\delta_{\mathrm{C}} 57.2\right)$ and from His $\alpha-\mathrm{CH}\left(\delta_{\mathrm{H}} 4.58\right)$ to Hse $\gamma$-CH $\left(\delta_{\mathrm{C}} 78.7\right)$, forming a $\gamma$-lactam. This partial structure was supported by long-range ${ }^{1} \mathrm{H}^{15} \mathrm{~N}$ couplings from Hse $\gamma-\mathrm{CH}$ and His $\alpha-\mathrm{CH}$ protons to His $\alpha-\mathrm{N}\left(\delta_{\mathrm{N}} 150.2\right)$. The $\gamma$-lactam structure was confirmed by the comparison of ${ }^{13} \mathrm{C}$ chemical shifts measured in $\mathrm{D}_{2} \mathrm{O}$ with $2 \%$ TFA and
Table 2. Comparison of the ${ }^{13} \mathrm{C}$ Chemical Shifts of 1 Measured in $\mathrm{D}_{2} \mathrm{O}$ with $2 \%$ TFA and $\mathrm{H}_{2} \mathrm{O}-\mathrm{D}_{2} \mathrm{O}(4: 1)$ with $2 \%$ TFA

\begin{tabular}{lccc}
\hline \hline Position & $\mathrm{D}_{2} \mathrm{O}+\mathrm{TFA}$ & $\mathrm{H}_{2} \mathrm{O}-\mathrm{D}_{2} \mathrm{O}+\mathrm{TFA}$ & $\Delta(\mathrm{ppm})$ \\
\hline $\mathrm{Aad} \varepsilon$ & 177.82 & 177.96 & 0.14 \\
$\mathrm{AcC}=\mathrm{O}$ & 174.64 & 174.82 & 0.18 \\
$\mathrm{Hse} \mathrm{C}=\mathrm{O}$ & 174.46 & 174.48 & 0.02 \\
$\operatorname{Pro} \mathrm{C}=\mathrm{O}$ & 173.29 & 173.36 & 0.07 \\
$\mathrm{Aad} \mathrm{C}=\mathrm{O}$ & 172.83 & 172.94 & 0.11 \\
$\mathrm{Arg} \mathrm{C}=\mathrm{O}$ & 172.48 & 172.51 & 0.03 \\
$\mathrm{His} \mathrm{C}=\mathrm{O}$ & 172.20 & 172.28 & 0.08 \\
$\mathrm{Arg} \zeta$ & 152.86 & 153.12 & 0.26 \\
$\mathrm{His} \varepsilon$ & 133.96 & 134.19 & 0.23 \\
$\mathrm{His} \gamma$ & 127.82 & 127.93 & 0.11 \\
$\mathrm{His} \delta$ & 116.98 & 117.11 & 0.13 \\
$\mathrm{Hse} \gamma$ & 79.88 & 79.99 & 0.11 \\
$\operatorname{Pro} \alpha$ & 60.83 & 60.87 & 0.04 \\
$\operatorname{His} \alpha$ & 57.68 & 57.75 & 0.07 \\
Aad $\alpha$ & 53.18 & 53.28 & 0.10 \\
$\operatorname{Arg} \alpha$ & 52.57 & 52.69 & 0.11 \\
Hse $\alpha$ & 50.27 & 50.40 & 0.14 \\
\hline
\end{tabular}

The spectra were obtained with a Varian Unity 400 spectrometer.

$\mathrm{H}_{2} \mathrm{O}-\mathrm{D}_{2} \mathrm{O}(4: 1)$ with $2 \%$ TFA (Table 2). Among seven carbonyl carbons, Hse carbonyl $\left(\delta_{\mathrm{C}} 174.46\right.$ in $\left.\mathrm{D}_{2} \mathrm{O}-\mathrm{TFA}\right)$ and Arg carbonyl $\left(\delta_{\mathrm{C}} 172.48\right.$ in $\left.\mathrm{D}_{2} \mathrm{O}-\mathrm{TFA}\right)$ signals showed small shifts $(\Delta 0.02-0.03 \mathrm{ppm})$, and the other carbonyls showed large shifts $(\geq \Delta 0.07 \mathrm{ppm})$. These deuterium isotope effects suggested that the former carbonyl carbons bonded tertiary nitrogens. Hse $\gamma-\mathrm{CH}\left(\delta_{\mathrm{C}} 79.88\right.$ in $\left.\mathrm{D}_{2} \mathrm{O}-\mathrm{TFA}\right)$ also showed a large shift $(\Delta 0.11 \mathrm{ppm})$, which suggested that a hydroxyl bonded the methine.

Attachment of acetyl residue (f) to $\omega$-terminal of Arg (a) was suggested from the ${ }^{1} \mathrm{H}-{ }^{13} \mathrm{C}$ and ${ }^{1} \mathrm{H}-{ }^{15} \mathrm{~N}$ long-range couplings between $\operatorname{Arg} \eta_{1}-\mathrm{NH}\left(\delta_{\mathrm{H}} 11.78\right)$ and acetyl carbonyl $\left(\delta_{\mathrm{C}} 172.7\right)$ and between acetyl $\mathrm{CH}_{3}\left(\delta_{\mathrm{H}} 2.10\right)$ and $\mathrm{Arg} \eta_{1}-\mathrm{NH}$ $\left(\delta_{\mathrm{N}} 133.3\right)$, respectively. The skeletal structure of $\mathbf{1}$ was thus elucidated. The two hydrogens missing in the ${ }^{1} \mathrm{H}$-NMR were deduced to be hydrogens of $\mathrm{Hse} \gamma-\mathrm{OH}$ and $\mathrm{Aad} \varepsilon-\mathrm{COOH}$ from the above result.

The optical activity of each amino acid was elucidated by chiral HPLC of acid hydrolysate of $\mathbf{1}$, which revealed the presence of $1 \mathrm{~mol}$ of L-arginine, D-proline and L-2-aminoadipic acid. Histidine and homoserine were not detected since they formed a $\gamma$-lactam complex that was not hydrolyzed to respective amino acid residues.

Combining the above results, the structure of 1 was elucidated as $\operatorname{cyclo}\left(N^{\omega}\right.$-acetyl-L-arginyl-D-prolyl-homoseryl-histidyl-L-2-aminoadipyl) in which homoseryl $\gamma$-methylene bonded to histidyl $\alpha$-amino residue.

Chitinase Inhibitory Activity Compound 1 inhibited chitinase from Lucilia cuprina (blowfly) dose dependently (Fig. 5). Inhibitory activity of 1 against $L$. cuprina chitinase was studied compared with that of argifin (2) and allosamidin ${ }^{3)}$ (Table 3). Compound $\mathbf{1}$ inhibited the chitinase with $\mathrm{IC}_{50}$ values of $150 \mathrm{~nm}$ at $37^{\circ} \mathrm{C}$ and $3.4 \mathrm{~nm}$ at $20^{\circ} \mathrm{C}$, and the inhibitory activities were about thirty times more potent than those of 2 . Allosamidin showed inhibition with $\mathrm{IC}_{50}$ values of $2.3 \mathrm{~nm}$ at $37^{\circ} \mathrm{C}$ and $0.40 \mathrm{~nm}$ at $20^{\circ} \mathrm{C}$. Therefore, 1 was only nine times weaker than allosamidin at $20^{\circ} \mathrm{C}$.

Cockroach Larvae Mortality by Injection Assay Compound $1(20$ or $2 \mu \mathrm{g} / 1 \mu \mathrm{l}$ of $0.1 \mathrm{~N} \mathrm{AcOH})$ was injected into twenty american cockroach (Periplaneta americana) larvae 


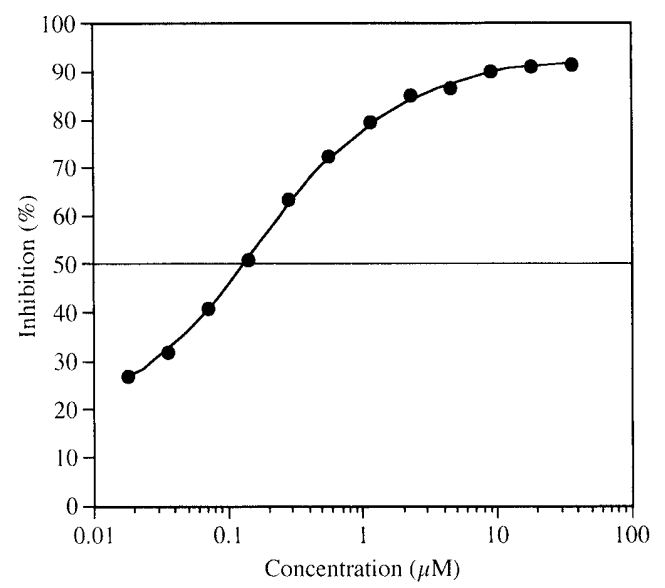

Fig. 5. Inhibition of Lucilia cuprina Chitinase by $\mathbf{1}$

The enzyme assay was carried out at $37^{\circ} \mathrm{C}$.

Table 3. Lucilia cuprina Chitinase Inhibition by Argadin, Argifin and Allosamidin

\begin{tabular}{lcc}
\hline & \multicolumn{2}{c}{$\mathrm{IC}_{50}(\mathrm{nM})$} \\
\cline { 2 - 3 } Compound & $37^{\circ} \mathrm{C}$ & $20^{\circ} \mathrm{C}$ \\
\hline Argadin (1) & 150 & 3.4 \\
Argifin (2) & 3700 & 100 \\
Allosamidin & 2.3 & 0.40 \\
\hline
\end{tabular}

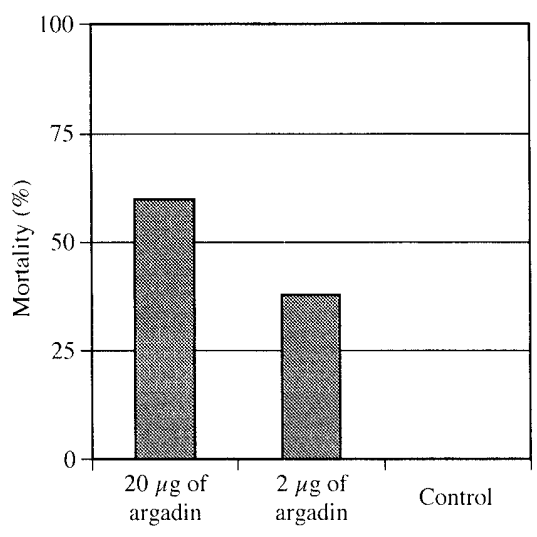

Fig. 6. Efficacy of $\mathbf{1}$ against Periplaneta americana Cockroach Larvae

and compared with mock injected controls $(1 \mu \mathrm{l}$ of $0.1 \mathrm{~N}$ $\mathrm{AcOH})$. Mortality was assessed at 1,5 and $23 \mathrm{~d}$ after injection. There was unexpectedly high control mortality $(35 \%)$ at day 1 . Therefore, the numbers of dead larvae at day 5 and day 23 were summed and are shown in Fig. 6. The efficacy of 1 was shown against the larval stage of cockroaches dose dependently. No mortality was observed for control cases after day 1 , while 60 and $38 \%$ mortality was observed for cockroaches injected with $20 \mu \mathrm{g}$ and $2 \mu \mathrm{g}$ of $\mathbf{1}$, respectively.

Mortality at day 1 may be due to the use of an acidic solvent to dissolve 1 as well as to mechanical disruption of the cockroaches by the injection. We have reported a cockroach assay of argifin (2) using water as a solvent ${ }^{7)}$; at that time, the control mortality at day 1 was only $12 \%$. Therefore, the acidic solvent may have enhanced the control death.

Other Biological Activities Argadin did not inhibit the growth of the following microorganisms at $10 \mu \mathrm{g} / \mathrm{disc}$ : Bacillus subtilis PCI 219, Micrococcus luteus PCI 1001, My- cobacterium smegmatis ATCC 607, Staphylococcus aureus FDA 209P, Acholeplasma laidlawii PG 8, Bacteroides fragilis ATCC 23745, Escherichia coli NIHJ, Pseudomonas aeruginosa $\mathrm{P} 3$, Xanthomonas campestris pv. oryzae $\mathrm{KB} 88$, Candida albicans KF 1, Saccharomyces cerevisiae KF 26, Aspergillus niger ATCC 6275, Mucor racemosus IFO 4581 or Pyricularia oryzae KF 180. Argadin also did not inhibit the growth of P388, KB or HL- 60 cells at $25 \mu \mathrm{g} / \mathrm{ml}$.

We isolated a new chitinase inhibitor, argadin (1), from the cultured broth of Clonostachys sp. FO-7314, after the isolation of 2 from the broth of Gliocladium sp. FTD-0668. Both $\mathbf{1}$ and $\mathbf{2}$ are cyclic pentapeptides containing $N^{\omega}$-substituted-Larginine. The guadinino group may be important for chitinase inhibition because known inhibitors, styloguanidines, ${ }^{4)}$ cyclo(L-arginyl-D-prolyl) ${ }^{5)}$ and compound $\mathrm{A},{ }^{9)}$ also have one or more guadinino groups. The producing strain of $\mathbf{2}$ was Gliocladium sp. which is close to the genus Clonostachys. Though there have so far been only two examples, the production of cyclic peptide chitinase inhibitors may be a genus specific event.

Chitinase is widely distributed in the group of bacteria, fungi, plants and arthropods, but it is not essential for mammals. Chitinase inhibitors would be expected to interfere with the life cycle of the former group, but not that of the latter. Therefore, cyclic pentapeptide containing $N^{\omega}$-substitutedL-arginine could be an interesting lead for the development of novel insecticides.

\section{Experimental}

General NMR spectra were obtained with Varian Inova 600 and Unity 400 spectrometers at room temperature using DMSO- $d_{6}$ with $1.7 \%$ TFA, $\mathrm{H}_{2} \mathrm{O}-\mathrm{D}_{2} \mathrm{O}(4: 1)$ with $2 \%$ TFA and $\mathrm{D}_{2} \mathrm{O}$ with $2 \%$ TFA as solvents.

${ }^{1} \mathrm{H}-{ }^{15} \mathrm{~N}$ HMBC was recorded on a Varian Unity 400 spectrometer equipped with pulse field gradients and an inverse detection $5 \mathrm{~mm}$ probe. Other conditions were as follows: sample $8.0 \mathrm{mg}$, solvent $0.6 \mathrm{ml}$ of $\mathrm{H}_{2} \mathrm{O}-\mathrm{D}_{2} \mathrm{O}(4: 1)$ with $2 \%$ TFA, $f_{1} \times f_{2}=13037 \times 3507 \mathrm{~Hz}, t_{1} \times t_{2}=64 \times 1024$ points, transients $=2032$, repetition time $=1.5 \mathrm{~s}$, relaxation delay optimized for $J=6 \mathrm{~Hz}$.

Mass spectrometry was conducted on a JEOL JMS-AX505 HA spectrometer. UV and IR spectra were measured with a Shimadzu UV-240 spectrophotometer and a Horiba FT-210 Fourier transform IR spectrometer, respectively. Optical rotation was recorded on a JASCO model DIP-181 polarimeter. Melting point was measured with a Yanaco micro melting point apparatus MP-S3.

4-Methylumbelliferone and 4-methylumbelliferyl- $\beta$-D- $N, N^{\prime}, N^{\prime \prime}$-triacetylchitotriose were obtained from Sigma Chemical Co.

Fermentation and Isolation The seed medium was composed of $2.0 \%$ glucose, $0.5 \%$ Polypepton (Nihon Pharmaceutical Co.), $0.1 \%$ agar, $0.2 \%$ yeast extract (Oriental Yeast Co.), $0.05 \% \mathrm{MgSO}_{4} \cdot 7 \mathrm{H}_{2} \mathrm{O}$ and $0.1 \% \mathrm{KH}_{2} \mathrm{PO}_{4}$ (pH 5.7 prior to sterilization). The production medium was composed of $5.0 \%$ maltose, $3.0 \%$ dry yeast (Gist-brocades), $1.0 \% \mathrm{KBr}, 0.5 \% \mathrm{KH}_{2} \mathrm{PO}_{4}$ and $0.05 \% \mathrm{MgSO}_{4} \cdot 7 \mathrm{H}_{2} \mathrm{O}(\mathrm{pH} 6.0$ prior to sterilization).

The cultured broth of FO-7314 (81) was filtered, and the mycelia were extracted with methanol (81) and concentrated in vacuo. The extract was diluted to 81 with water, neutralized, and charged on a Diaion SKIB cation exchange column $\left(\mathrm{NH}_{4}{ }^{+}\right.$form, $\left.800 \mathrm{ml}\right)$. After washing with water, the active substance was eluted with $0.5-2.0 \mathrm{~N} \mathrm{NH}_{4} \mathrm{OH}$. The eluate was neutralized and applied on a Diaion HP20 column $(800 \mathrm{ml})$. The column was washed with water and eluted with $10-80 \%$ methanol. The eluate was concentrated in vacuo and dissolved in a small amount of $15 \mathrm{~mm}$ ammonium acetate. The solution was charged on an SP-Sephadex C-25 cation exchange column $\left(\mathrm{NH}_{4}{ }^{+}\right.$form, $\left.800 \mathrm{ml}\right)$. After washing with $50 \mathrm{~mm}$ ammonium acetate, the active substance was eluted with $100 \mathrm{~mm}$ ammonium acetate. The active fractions were collected and applied on an ODS column (Pegasil ODS-7515$12 \mathrm{~A}, 200 \mathrm{ml}$ ). After washing with water, the active substance was eluted with $100 \mathrm{ml}$ of $40 \%$ methanol. The eluate was concentrated in vacuo and dissolved in a small amount of $65 \%$ methanol. The solution was charged on a Sephadex LH-20 column $(800 \mathrm{ml})$ and eluted with $65 \%$ methanol. The ac- 
tive fractions were collected and concentrated in vacuo, then dissolved in a small amount of $0.05 \%$ acetic acid, charged on a Bio-Gel P-2 Gel column (fine, $800 \mathrm{ml}$ ), and eluted with $0.05 \%$ acetic acid. The active fractions were collected and concentrated in vacuo to yield a white powder of pure 1 (25 mg).

Argadin (1): White powder, $[\alpha]_{\mathrm{D}}^{25}+52.1^{\circ}\left(c=0.1, \mathrm{H}_{2} \mathrm{O}\right) . \mathrm{C}_{29} \mathrm{H}_{43} \mathrm{~N}_{10} \mathrm{O}_{9}$ $\left(\mathrm{m} / \mathrm{z} 675.3214(\mathrm{M}+\mathrm{H})^{+}\right.$; Calcd for $\left.\mathrm{C}_{29} \mathrm{H}_{43} \mathrm{~N}_{10} \mathrm{O}_{9}, 675.3214\right)$ by HR-FABMS. mp $270^{\circ} \mathrm{C}$ (dec.). UV $\lambda_{\max }\left(\mathrm{H}_{2} \mathrm{O}\right) \mathrm{nm}(\varepsilon): 200(31400)$. IR $v_{\max }(\mathrm{KBr})$ $\mathrm{cm}^{-1}: 3310,3220,1710,1650,1575,1530,1435,1390,1245$.

Acid Hydrolysis of 1 Compound $1(100 \mu \mathrm{g})$ was hydrolyzed with $6 \mathrm{~N}$ $\mathrm{HCl}-1 \%$ phenol vapor at $120^{\circ} \mathrm{C}$ for $11 \mathrm{~h}$. The reaction mixture was concentrated to dryness, dissolved in a small amount of water, and charged on a chiral HPLC: column, Sumichiral OA-5000 (Sumika Chemical Analysis Service, i.d. $4.6 \times 150 \mathrm{~mm}$ ); mobile phase, $1 \mathrm{~mm} \mathrm{CuSO}_{4}$; flow rate $1.0 \mathrm{ml} / \mathrm{min}$; detection, UV $254 \mathrm{~nm}$.

The amino acid peaks were identified by co-injection of each authentic optically pure sample: The molar ratios of amino acids were calculated from the peak area.

Assay Methods for Biological Activities Chitinase inhibitory activity was measured as described previously. ${ }^{7)}$ In brief, $20 \mu \mathrm{l}$ of $100 \mathrm{~mm}$ sodium phosphate buffer, $\mathrm{pH} 7.0,30 \mu \mathrm{l}$ of crude chitinase solution (prepared from late pupae of the blowfly, Lucilia cuprina), and $50 \mu \mathrm{l}$ of $80 \mu \mathrm{m}$ 4-methylumbelliferyl- $\beta$-D- $N, N^{\prime}, N^{\prime \prime}$-triacetylchitotriose in the buffer were placed in each well of a microplate, and incubated with or without the sample at $37^{\circ} \mathrm{C}$ for $10 \mathrm{~min}$ or $20^{\circ} \mathrm{C}$ for $15 \mathrm{~min}$. Fluorescence (excitation at $355 \mathrm{~nm}$, emission at $460 \mathrm{~nm}$ ) was measured by a fluorometer (Fluoroscan II, Labsystems), and the rate of 4-methylumbelliferone production was corrected by calibrating the quenching ratio of each sample using the mixture of the sample and 4methylumbelliferone.
Assay methods for antimicrobial activity and cockroach larvae injection were also described previously. ${ }^{\text {? }}$

Acknowledgements We thank Mr. Marek Rygol, Bayer AG, for his skillful technical assistance in the cockroach injection trials. We also thank Dr. Hideaki Ui, the Kitasato Institute, and Ms. Akiko Hatano, School of Pharmaceutical Sciences, Kitasato University, for NMR experiments. We are grateful to Dr. Shohei Sakuda, the University of Tokyo, for his generous gift of allosamidin. This work was supported in part by a grant from the Japan Keirin Association.

\section{References}

1) Spindler K.-D., Spindler-Barth M., Londershausen M., Parasitol. Res., 76, 283-288 (1990).

2) Londershausen M., Turberg A., Bieseler B., Lennartz M., Peter M. G., Pesticide Sci., 48, 305-314 (1996).

3) Koga D., Isogai A., Sakuda S., Matsumoto S., Suzuki A., Kimura S., Ide A., Agric. Biol. Chem., 51, 471-476 (1987).

4) Kato T, Shizuri Y., Izumida H., Yokoyama A., Endo M., Tetrahedron Lett., 36, 2133-2136(1995).

5) Izumida H., Imamura N., Sano, H., J Antibiot., 49, 76-80 (1996).

6) Shiomi K., Arai N., Iwai Y., Turberg A., Kölbl H., Ōmura S., Tetrahedron Lett., 41, 2141-2143 (2000).

7) Ōmura S., Arai N., Yamaguchi Y., Masuma R., Iwai Y., Namikoshi M., Turberg A., Kölbl H., Shiomi K., J. Antibiot., 53, 603-608 (2000).

8) Arai N., Shiomi K., Iwai Y., Ōmura S., J. Antibiot., 53, 609-614 (2000).

9) Yokoyama, A., Shizuri, Y., Jpn. Patent Appl., 11-80138 (1999). 